\title{
Diagnosis of the applications of Continuous Learning of Watkins and Marsick Model in IT Industry of Indian Silicon Valley
}

\author{
MANOHAR SHETTY \\ ISO Lead Auditor, Shetty \& Co., Cambridge (UK).
}

\begin{abstract}
Each organization must turn into a learning association. Pioneers may think articulating a reasonable vision, the exact motivating forces for workers and giving preparing make associations to learn. This suspicion is not simply imperfect - it's hazardous despite heightened rivalry, progresses in innovation, and movements in client inclinations. In element complex circumstances cause and impacts are available in unobtrusive structures, yet the aftereffects of mediations are not instantly observable. In perspective of Watkins and Marsick, authoritative learning started with a shared perception that critical learning, Continuous Learning - It is the center of a fruitful association flourishing to increase focused edge over different organizations in a solid aggressive business. The goal of the study incorporates To determine the acts of Watkins and Marsick model in IT industry through Continuous Learning. Examination works together Moderate to High rankings for different components of Continuous Learning under demographic variables - Age, sexual orientation, Education, Occupation and Income. Exploration finishes up serious utilization of Continuous Learning in IT industry under demographic division variables. The movement from customary techniques to advanced strategies for Learning Organization practices is because of interest from the business and can even finish up giving Continuous Learning is have to associations in the dynamic association environment.
\end{abstract}

Key words: Watkins and Marsick Model, Continuous Learning, stiff competitive market, dynamic organization environment.

\section{INTRODUCTION}

The significance of learning was first advanced by the Chinese logician Confucius. He trusted that everybody ought to profit by learning. Innovative headway and the information based economy made a disordered situation and savage rivalry that requires associations to be prepared to take in more than at any other time in recent memory some time recently. Along these lines associations attempt to have a learning association that plans to make, get and exchange information and change its conduct to reflect new information and bits of knowledge. Looking for perfection, associations are finding intends to tap representative's potential, determine duty and build up the chances to learn at all levels for hierarchical workers. Individual learning does not guarantee authoritative learning. Be that as it may, hierarchical adapting never happens without it. We reproduce ourselves through learning and have the capacity to do which we were not able to do prior. We re-see the world and relationship to it through learning. We extend our ability to make, to be a piece of the generative procedure of life through learning.

\section{LEARNING ORGANIZATION:}

Each organization must turn into a learning association. Pioneers may think articulating an unmistakable vision, the precise motivations for workers and giving preparing make associations to learn. This presumption is not simply defective - it's unsafe despite increased rivalry, propels in innovation, and movements in client inclinations. In element complex circumstances cause and impacts are available in unpretentious structures, however the aftereffects of intercessions are not instantly observable. Senge contends that changing into learning associations is the compelling route for associations to oversee dynamic and complex change, and to acknowledge key targets.

Work environments are changing at incremental rates as a result of their mental contract and the requests on representatives at all levels to learn and work speedier. Associations expect that learning and information creation happens persistently for people and that they will share what they realize that advance learning in groups all through the association. Human asset improvement proactively impact the bearing, pace and remarkable quality of learning in associations. 
Definitions:

The learning company is a vision of what might be possible. It is not brought about simply by training individuals; it can only happen as a result of learning at the whole organization level. A learning company is an organization that facilitates the learning of all its members and continuously transforms itself.

Pedler, et al $1991^{8}$

Learning organizations are characterized by total employee involvement in a process of collaboratively conducted, collectively accountable change directed towards shared values or principles.

Watkins and Marsick, $1992^{9}$

\section{MODELS OF LEARNING ORGANIZATION - Watkins and Marsick Model}

In perspective of Watkins and Marsick, authoritative learning started with a common perception that noteworthy adapting, even transformative learning, was generally the minimum organized. Yet models of grown-up learning were by and large in light of a supposition of an instructor organizing learning encounters. Organized preparing is still esteemed and essential, for instance, as epitomized in competency models or execution innovation. In any case, there is an expanded mindfulness that much important learning happens casually at work, in gatherings, or through discussions (J. M. Huber Institute for Learning in Organizations, 2002). To bolster such realizing, one needs to fabricate a learning atmosphere and society. Atmosphere and society are assembled by pioneers and other key individuals who gain from their experience, impact the learning of others, and make a domain of desires that shapes and backings coveted results that thus get measured and remunerated.

- $\quad$ Continuous Learning - It is the center of an effective association flourishing to increase focused edge over different organizations in a solid aggressive business sector; here the association offers the representatives a chance to learn without anyone else's input all through their professions, with an extreme target of high profitability.

- $\quad$ Inquiry \& Dialog - Organizational learning requires proficient request as a premise (Senge \& Joni, 2005). Watkins and Marsick recognized request as "liberal interest that empowers us to suspend our presuppositions and judgments in light of a legitimate concern for truth or a superior arrangement" as an association between individual learning and group learning (p. 74).

- $\quad$ Team Learning - Team learning serves as a critical impetus giving people inside of associations chances to cooperate in a domain of self-guided learning through which they may trade thoughts and examination through generative figuring out how to address authoritative issues or issues while progressing in the direction of creative arrangements.

- $\quad$ Embedded Systems - To manage aggressive and positive execution results it is important to association to create intends to insert the new learning into the corporate memory.

- $\quad$ Empowerment - Leaders must enable people to draw in authoritative goals inside of a domain and everybody accept obligation shattering so as to regard accomplishment the bureaucratic administration worldview. Engaged people of associations perceive more prominent potential for advancement prompting the improvement of new thoughts and ideas.

- $\quad$ System Connections - This measurement obliges a comprehension of frameworks intuition with respect to the association and its inner and outside environment. A mixed bag of matters inside and outside of the association communicate bringing about a transference of impact - a methodical impact a reason conveys into another environment prompting another impact inside of that new environment.

- $\quad$ Strategic Leadership - The part of authority in the improvement of the learning association is essential as pioneers build up the atmosphere and society of the association. These pioneers and other key people "gain from their encounters, impact the learning of others, and make a domain of desires that shapes and backings wanted results that thus get measured and compensated" (Marsick \& Watkins, 2003, p. 134).

\section{NEED FOR THE STUDY}

Going astray from Chapter I which gave a brief setting of the study, this section harps on depleting writing on the issues that have direct influence on representative states of mind and practices to preparation for hierarchical 
change/advancement. Significantly, these bits of knowledge highlight the way that representative availability for authoritative change is basic for effective usage of Employee Career Development Programs, and subsequently fortify the requirement for the study. The target of ECD is to enhance the association's ability to handle its inner and outside working and connections. This would incorporate such things as enhanced interpersonal and gathering procedures, more successful correspondence, upgraded capacity to adapt to hierarchical issues of different sorts, more powerful choice procedures, more suitable authority style, enhanced expertise in managing dangerous clash, and larger amounts of trust and participation among authoritative individuals.

\section{NEED FOR THE STUDY:}

The target of Learning Organization is to enhance the individual's and association's ability to handle its inside and outside learning and working. This would incorporate such things as enhanced interpersonal and gathering procedures, more powerful correspondence, upgraded capacity to adapt to authoritative issues of assorted types, more viable choice procedures, more proper administration style, enhanced aptitude in managing dangerous clash, and more elevated amounts of trust and participation among hierarchical individuals. These goals stem from a worth framework taking into account an idealistic perspective of the way of man — that man in a steady situation is fit for accomplishing larger amounts of advancement and achievement. Fundamental to presence of learning association and adequacy is the exploratory strategy — request, a thorough quest for reasons, trial testing, and survey of results.

\section{SCOPE OF THE STUDY:}

The motivation behind learning association is to address perpetual advancing needs of fruitful associations - a purposeful cooperation of interior and outer specialists in the field to find the procedure an association can use to wind up more partners successful. Learning Organization is a long lasting, assembled in system to enhance resistance of association's wellbeing to reestablish itself. Specialists in frameworks speculation and authoritative learning, personality maps, body mind synchronicity, structure of instinct in choice making, and guiding (to give some examples) whose point of view is not saturated with simply the behavioral sciences, but rather an a great deal more multi-disciplinary and between disciplinary methodology have risen as Chief Learning Officers. These emanant master viewpoints see the association as the all encompassing exchange of various frameworks that effect the procedure and yields of the whole association. All the more essentially, the term change specialists or impetus is synonymous with the thought of a pioneer who is occupied with initiative - a transformative or adequacy process - rather than administration, a more incremental or productivity based change approach.

\section{RESEARCH METHODOLOGY:}

The present exploration mull over entirely submits to the reasonable edge work articulated by the subject Research Methodology for the configuration and behavior of the examination, this piece of the study goes for showing every one of the parts of the examination in an unmistakable style which incorporates Statement of the issue, Objectives of the study, Hypotheses detailing, Data gathering, Data preparing, elucidation or Description, at long last took after by exhibiting the Findings and Conclusions of the study. All components in different phases of examination procedure are clarified spellbindingly, offering due significance to them and treating them exclusively and unmistakably.

\section{PROCLAMATION OF THE PROBLEM}

Parameters winning for estimation of advancement rely on upon Physical, Human, Financial, and Information assets in all associations notwithstanding, during the time spent learning association applications representatives do experience issues that are resultant of the above strengths. Taking care of or tackling these issues is the point of the LO which means to upgrade representative's capacities in all things considered figuring out how to take care of the issues in a hierarchical situation. Use of LO models in different firms in IT industry at Bangalore and Hyderabad accept essentialness in the scenery of hardened rivalry. Consequently, assessment of LO measurements managing the improvement of representative abilities for hierarchical advancement through aggregate Learning endeavors it could call its own worker from all levels of the association shapes the center piece of the present research.

\section{OBJECTIVE OF THE STUDY}


Primary

- To ascertain the practices of 'Learning Organization' in IT industry.

Secondary

- To ascertain the practices of Watkins and Marsick model in IT industry.

\section{HYPOTHESIS}

Primary

Secondary

$\mathrm{H}_{01} \quad$ 'Learning Organization' do not influence employee learning in IT industry.

$\mathrm{H}_{02} \quad$ Watkins and Marsick Model do not influence employee learning in IT Industry

\section{SAMPLING}

\section{Testing Plan}

The specimen arrangement comprises of picking representatives from IT businesses for the study from the land district of Hyderabad and Bangalore urban communities. Further, the aggregate size and piece of IT workers of the IT firms shape the base for recommending no and size of respondents to be drawn from different various leveled levels of the IT firms.

\section{Universe}

Includes aggregate number of Male and Female workers at different various leveled levels of all IT firms at Hyderabad and Bangalore urban areas.

\section{Test size}

It is a corresponding representation of the worker thickness at a given area, firms and their different various leveled levels. The exploration study by NASSCOM affirms a $20.3 \%$ and $10.7 \%$ of IT modern area representation for Bangalore and Hyderabad separately. 'Report of India Law workplaces' excessively affirms the same. These reports frame the base for altering the example size of 288 and 519 for Hyderabad and Bangalore individually.

Inspecting Technique

The procedure of drawing example respondents from the specimen universe is known as inspecting strategy, among numerous strategies accessible Stratified examining is utilized for the reason since it is more fitting as the example respondents are conveyed in diverse associations as stratified gatherings at distinctive various leveled levels of the organizations. The authoritative setting of the worker pre decides the suitability of the testing method making the practice more significant, proper and pertinent.

\section{STATISTICAL ANALYSIS:} distinctive levels.

In the first stage the information gathered through survey offers weightage for the workers of

- In the second stage number of respondents demonstrating distinctive weightage for every component of the idea is shown, at last prompting the quantity of respondents showing diverse weightages.

- In the third stage weighted midpoints are landed at, which prompt combined weighted normal for every idea by 428 respondents.

- In the fourth stage chi-square test is performed to determine the level of criticalness.

- The fifth and last stage comprise of appropriating respondents as indicated by chi-square values Vs demography and weighted normal Vs demography. 
Combined Weighted Average is utilized to depict the profile of the respondents and their conduct in the different phases of representative vocation advancement rehearses.

Chi-Square Test: - is utilized with the end goal of testing the impact of one variable on the other. The test has been controlled to contemplate the impact of the demographic variables, identity attribute and state of mind of representatives.

\section{LIMITATIONS OF THE STUDY:}

An exploration investigation of this nature couldn't be completed with no restrictions. Thus this examination study is constrained to mainly the populace, target populace and test populace as their conclusions, mentalities there on the discoveries of the study. Second component is the time element which applies heavenly impact on the sentiment of test populace.

In an investigation of this greatness however, fastidious consideration has been taken in every last part of study.

1. A few respondents were not mindful of specific ideas and systems.

2. A couple of respondents were reluctant to give careful points of interest.

3. There may be a feeling of inclination wormed in answers given by the respondents.

In spite of the above restrictions, the specialist put in all his earnest attempts in beating the confinements and in finishing the study. 
1.12 Data Analysis \& Interpretation

Table. No: 1.0

Continuous Learning - Age wise

\begin{tabular}{|c|c|c|c|c|c|c|c|c|c|c|c|c|c|c|}
\hline & \multicolumn{7}{|c|}{ Bengaluru } & \multicolumn{7}{|c|}{ Hyderabad } \\
\hline Element Age & $21-25$ & $26-30$ & $31-35$ & $36-40$ & $41-45$ & $>45$ & $C W A$ & $21-25$ & $26-30$ & $31-35$ & $36-40$ & $41-45$ & $>45$ & $C W A$ \\
\hline $\begin{array}{l}\text { Employee Learning } \\
\text { Through Open Discussion } \\
\text { on Mistakes }\end{array}$ & 2.95 & 3.09 & 2.91 & 2.98 & 3.16 & 3.09 & 3.03 & 3.07 & 2.90 & 3.12 & 2.97 & 2.90 & 3.00 & 2.99 \\
\hline $\begin{array}{l}\text { Employee identification of } \\
\text { skills for future task } \\
\text { accomplishment }\end{array}$ & 4.01 & 3.93 & 4.02 & 3.95 & 3.95 & 3.85 & 3.95 & 3.98 & 3.96 & 3.90 & 3.89 & 4.00 & 3.89 & 3.94 \\
\hline $\begin{array}{l}\text { Mutual Employee Efforts } \\
\text { at Learning }\end{array}$ & 2.15 & 2.11 & 2.05 & 2.05 & 1.86 & 1.88 & 2.02 & 2.09 & 2.03 & 1.96 & 1.94 & 2.00 & 1.89 & 1.99 \\
\hline $\begin{array}{l}\text { Availability of fund and } \\
\text { other resources for } \\
\text { Employee to support their } \\
\text { learning }\end{array}$ & 3.04 & 3.03 & 3.18 & 3.02 & 3.16 & 2.82 & 3.04 & 3.11 & 2.85 & 3.18 & 2.89 & 2.81 & 3.00 & 2.97 \\
\hline $\begin{array}{l}\text { Availability of time to } \\
\text { support learning }\end{array}$ & 3.02 & 3.02 & 2.98 & 3.03 & 3.12 & 2.82 & 3.00 & 3.06 & 2.85 & 3.06 & 2.81 & 3.19 & 3.00 & 2.99 \\
\hline $\begin{array}{l}\text { Employee treating job } \\
\text { related problems as an } \\
\text { opportunity to learn }\end{array}$ & 3.01 & 3.03 & 3.02 & 2.97 & 3.05 & 2.94 & 3.00 & 3.02 & 2.91 & 2.98 & 2.69 & 3.00 & 2.78 & 2.90 \\
\hline $\begin{array}{l}\text { Reward to encourage } \\
\text { employee learning }\end{array}$ & 3.99 & 3.90 & 4.03 & 3.98 & 3.98 & 3.94 & 3.97 & 3.95 & 3.99 & 3.94 & 3.94 & 3.90 & 4.00 & 3.95 \\
\hline Average & 3.17 & 3.16 & 3.17 & 3.14 & 3.18 & 3.05 & 3.14 & 3.18 & 3.07 & 3.16 & 3.02 & 3.12 & 3.08 & 3.10 \\
\hline
\end{tabular}




\section{STATUS}

Table 1.0 embodies "High" positioning for 'Representative Learning Through Open Discussion on Mistakes', 'Worker recognizable proof of aptitudes for future errand achievement', 'Accessibility of trust and different assets for Employee to bolster their learning', 'Accessibility of time to bolster learning', 'Worker regarding occupation related issues as a chance to learn' and 'Prize to empower representative learning' of the idea with special case of 'Common Employee Efforts at Learning' which is positioned "Impartial" by the example respondents, this is predominant among all age bunches in Bengaluru. The table likewise represents "High" positioning for 'Worker ID of abilities for future errand achievement' and 'Prize to empower representative learning', "Nonpartisan" positioning for 'Representative Learning through Open Discussion on Mistakes', 'Accessibility of trust and different assets for Employee to bolster their learning', 'Accessibility of time to bolster learning', and 'Worker regarding occupation related issues as a chance to learn' and "Low" positioning for 'Common Employee Efforts at Learning' for the predominance of the idea in Hyderabad locale. In this manner, high and unbiased levels of execution of the idea 'Nonstop Learning' are affirmed by the exploration.

\section{ASSESSMENT}

High positioning for six component and unbiased rankings for a component preludes the scientist to propose the high importance connected to everything except one component of the idea in the specimen IT associations in Bengaluru, High positioning for two components, Neutral for four components and Low positioning for one component prefaces the specialist to propose high hugeness appended to two components of the idea in the example IT associations in Hyderabad.

Table. No: 1.1

\begin{tabular}{|l|c|c|c|c|c|c|}
\hline \multicolumn{1}{|c|}{ Continuous Learning - Gender wise } \\
\hline \multicolumn{1}{|c|}{ Gender } & \multicolumn{3}{|c|}{ Bengaluru } & \multicolumn{3}{c|}{ Hyderabad } \\
\hline Element & Male & Female & CWA & Male & Female & CWA \\
\hline $\begin{array}{l}\text { Employee Learning Through Open } \\
\text { Discussion on Mistakes }\end{array}$ & 3.00 & 3.11 & 3.06 & 2.99 & 2.90 & 2.95 \\
\hline $\begin{array}{l}\text { Employee identification of skills for } \\
\text { future task accomplishment }\end{array}$ & 3.88 & 3.93 & 3.90 & 3.83 & 4.00 & 3.92 \\
\hline Mutual Employee Efforts at Learning & 2.06 & 2.08 & 2.07 & 2.07 & 2.09 & 2.08 \\
\hline $\begin{array}{l}\text { Availability of fund and other } \\
\text { resources for Employee to support } \\
\text { their learning }\end{array}$ & 3.02 & 2.90 & 2.96 & 3.15 & 3.02 & 3.09 \\
\hline $\begin{array}{l}\text { Availability of time to support } \\
\text { learning }\end{array}$ & 3.06 & 2.88 & 2.97 & 3.18 & 3.06 & 3.12 \\
\hline $\begin{array}{l}\text { Employee treating job related } \\
\text { problems as an opportunity to learn }\end{array}$ & 3.03 & 2.84 & 2.93 & 3.12 & 3.08 & 3.10 \\
\hline $\begin{array}{l}\text { Reward to encourage employee } \\
\text { learning }\end{array}$ & 3.95 & 3.99 & 3.97 & 3.81 & 3.97 & 3.89 \\
\hline Average & 3.14 & 3.10 & 3.12 & 3.17 & 3.16 & 3.16 \\
\hline
\end{tabular}

\section{STATUS}

Table 1.1 illustrates "High" positioning for 'Representative Learning through Open Discussion on Mistakes', 'Worker ID of abilities for future errand achievement' and 'Prize to support worker learning' and "Unbiased" positioning for four components as demonstrated by the conclusions of the specimen respondents, the rankings are going between 3-4 and 2-3 on the Likert scale, the same is winning among the two sexes in Bengaluru. The table additionally illustrates "High" positioning for five components and "Unbiased" positioning for two components for 
the pervasiveness of the idea in Hyderabad locale. Consequently, high and nonpartisan levels of usage of the idea 'Consistent Learning' are affirmed by the examination.

\section{ASSESSMENT}

High positioning for three components and unbiased positioning for four components preludes the specialist to propose the high centrality connected to the everything except four components of the idea in Bengaluru locale and high positioning for five components and nonpartisan positioning for two components preludes the analyst to propose the high noteworthiness joined to everything except two components of the idea in Hyderabad area by in the specimen IT associations. 


\begin{tabular}{|c|c|c|c|c|c|c|c|c|c|c|c|c|}
\hline \multicolumn{13}{|c|}{ Continuous Learning - Education wise } \\
\hline \multirow[b]{2}{*}{ Education } & \multicolumn{6}{|c|}{ Bengaluru } & \multicolumn{6}{|c|}{ Hyderabad } \\
\hline & M.Tech & B.Tech & $M C A / M S c$ & $M B A$ & Others & $C W A$ & M.Tech & B.Tech & $M C A / M S c$ & $M B A$ & Others & $C W A$ \\
\hline $\begin{array}{l}\text { Employee Learning Through } \\
\text { Open Discussion on Mistakes }\end{array}$ & 2.97 & 2.96 & 2.95 & 2.92 & 2.86 & 2.93 & 2.97 & 2.91 & 2.96 & 3.12 & 2.95 & 2.95 \\
\hline $\begin{array}{l}\text { Employee identification of skills } \\
\text { for future task accomplishment }\end{array}$ & 3.92 & 3.96 & 3.94 & 4.06 & 3.97 & 3.97 & 3.81 & 3.71 & 4.07 & 3.92 & 3.82 & 3.86 \\
\hline $\begin{array}{l}\text { Mutual Employee Efforts at } \\
\text { Learning }\end{array}$ & 2.05 & 2.07 & 2.39 & 2.11 & 1.97 & 2.12 & 2.00 & 2.01 & 2.04 & 2.00 & 2.08 & 2.03 \\
\hline $\begin{array}{l}\text { Availability of fund and other } \\
\text { resources for Employee to } \\
\text { support their learning }\end{array}$ & 2.98 & 2.97 & 3.00 & 2.94 & 2.87 & 2.95 & 3.00 & 2.92 & 2.98 & 3.04 & 2.90 & 2.97 \\
\hline $\begin{array}{l}\text { Availability of time to support } \\
\text { learning }\end{array}$ & 3.05 & 2.98 & 3.01 & 2.97 & 2.90 & 2.98 & 2.97 & 2.98 & 3.04 & 2.94 & 3.00 & 2.99 \\
\hline $\begin{array}{l}\text { Employee treating job related } \\
\text { problems as an opportunity to } \\
\text { learn }\end{array}$ & 3.09 & 2.99 & 3.04 & 3.03 & 2.93 & 3.02 & 3.00 & 2.95 & 3.02 & 3.07 & 2.85 & 2.98 \\
\hline $\begin{array}{l}\text { Reward to encourage employee } \\
\text { learning }\end{array}$ & 3.98 & 3.99 & 3.95 & 4.02 & 4.00 & 3.99 & 3.92 & 3.74 & 4.09 & 3.96 & 3.92 & 3.92 \\
\hline Average & 3.15 & 3.13 & 3.18 & 3.15 & 3.07 & 3.14 & 3.10 & 3.03 & 3.17 & 3.15 & 3.07 & 3.10 \\
\hline
\end{tabular}

\section{STATUS}

Table 1.2 displays "High" positioning for 'Representative distinguishing proof of abilities for future undertaking achievement', 'Worker regarding occupation related issues as a chance to learn' and 'Prize to energize worker learning' and "Impartial" positioning for 'Representative Learning Through Open Discussion on Mistakes', 'Common Employee Efforts at Learning', 'Accessibility of store and different assets for Employee to bolster their learning', and 'Accessibility of time to bolster learning' of the idea, this is winning among all instruction qualifiers in Bengaluru. The table likewise displays "High" positioning for 'Worker distinguishing proof of aptitudes for future undertaking achievement' and 'Prize to energize representative learning' and "Impartial" positioning for 'Worker Learning Through Open Discussion on Mistakes', 'Common Employee Efforts at Learning', 'Accessibility of trust and different assets for Employee to bolster their learning', 'Accessibility of time to bolster learning' and 'Worker regarding 
occupation related issues as a chance to learn' for the commonness of the idea in Hyderabad district. In this manner, abnormal amounts of execution of the idea 'Ceaseless Learning' are affirmed by the examination.

\section{ASSESSMENT}

High positioning for three components and impartial positioning for four components preludes the analyst to prescribe the high importance connected to the everything except four components of the idea in Bengaluru locale and high positioning for two components and unbiased positioning for five components lead up the scientist to prescribe the high hugeness appended to everything except five components of the idea in Hyderabad district by in the specimen IT associations.

Table. No: 1.3

\begin{tabular}{|c|c|c|c|c|c|c|c|c|c|c|c|c|c|c|}
\hline \multicolumn{15}{|c|}{ Continuous Learning - Occupation wise } \\
\hline & \multicolumn{7}{|c|}{ Bengaluru } & \multicolumn{7}{|c|}{ Hyderabad } \\
\hline $\begin{array}{l}\text { Occupation } \\
\text { Element }\end{array}$ & $\begin{array}{c}\text { Delivery } \\
\text { Head }\end{array}$ & $\begin{array}{c}\text { Archite } \\
\text { ct }\end{array}$ & $\begin{array}{l}\text { Project } \\
\text { Manager }\end{array}$ & $\begin{array}{l}\text { Team } \\
\text { Leader }\end{array}$ & SSW & SWE & CWA & $\begin{array}{c}\text { Delivery } \\
\text { Head }\end{array}$ & Architect & $\begin{array}{l}\text { Project } \\
\text { Manager }\end{array}$ & $\begin{array}{l}\text { Team } \\
\text { Leader }\end{array}$ & SSW & SWE & CWA \\
\hline $\begin{array}{l}\text { Employee } \\
\text { Learning } \\
\text { Through Open } \\
\text { Discussion on } \\
\text { Mistakes } \\
\end{array}$ & 3.05 & 2.94 & 2.96 & 3.07 & 3.00 & 2.92 & 2.99 & 3.09 & 3.00 & 2.92 & 3.06 & 2.98 & 2.90 & 2.99 \\
\hline $\begin{array}{l}\text { Employee ident- } \\
\text { ification of skills } \\
\text { for future task } \\
\text { accomplishment }\end{array}$ & 4.00 & 4.00 & 3.91 & 3.93 & 3.94 & 4.01 & 3.97 & 3.91 & 4.00 & 4.04 & 4.03 & 4.02 & 3.93 & 3.99 \\
\hline $\begin{array}{l}\text { Mutual Emplo- } \\
\text { yee Efforts at } \\
\text { Learning }\end{array}$ & 2.00 & 2.00 & 2.02 & 2.12 & 2.11 & 2.06 & 2.05 & 2.09 & 2.00 & 1.96 & 2.00 & 2.00 & 2.12 & 2.03 \\
\hline $\begin{array}{l}\text { Availability of } \\
\text { fund and other } \\
\text { resources for } \\
\text { Employee to } \\
\text { support their } \\
\text { learning }\end{array}$ & 3.11 & 3.03 & 2.98 & 3.07 & 3.01 & 2.93 & 3.02 & 3.00 & 3.14 & 2.85 & 3.09 & 3.06 & 2.93 & 3.01 \\
\hline Availability of & 2.95 & 2.94 & 3.02 & 3.02 & 2.98 & 2.93 & 2.97 & 2.91 & 2.93 & 2.92 & 3.03 & 2.98 & 2.95 & 2.95 \\
\hline
\end{tabular}




\begin{tabular}{|c|c|c|c|c|c|c|c|c|c|c|c|c|c|c|}
\hline $\begin{array}{l}\text { time to support } \\
\text { learning }\end{array}$ & & & & & & & & & & & & & & \\
\hline $\begin{array}{l}\text { Employee } \\
\text { treating job rela- } \\
\text { ted problems as } \\
\text { an opportunity } \\
\text { to learn }\end{array}$ & 3.11 & 3.00 & 3.04 & 2.98 & 3.00 & 2.94 & 3.01 & 3.09 & 3.00 & 2.96 & 3.00 & 3.02 & 2.96 & 3.01 \\
\hline $\begin{array}{l}\text { Reward to } \\
\text { encourage } \\
\text { employee } \\
\text { learning }\end{array}$ & 4.05 & 4.06 & 3.93 & 4.00 & 3.95 & 4.01 & 4.00 & 4.00 & 3.93 & 4.00 & 4.06 & 4.04 & 4.09 & 4.02 \\
\hline Average & 3.18 & 3.14 & 3.12 & 3.17 & 3.14 & 3.11 & 3.14 & 3.16 & 3.14 & 3.09 & 3.18 & 3.16 & 3.13 & 3.14 \\
\hline
\end{tabular}

\section{STATUS}

Table 1.3 shows 'High' positioning for 'Prize to empower worker adapting', "High" positioning for 'Representative ident-ification of aptitudes for future errand achievement', 'Accessibility of store and different assets for Employee to bolster their learning', and 'Worker regarding employment rela-ted issues as a chance to learn' and "Impartial" positioning for 'Worker Learning Through Open Discussion on Mistakes', 'Shared Emplo-yee Efforts at Learning', and 'Accessibility of time to bolster learning'as mark by the philosophy of the example respondents, this is existing among the distinctive occupations for the commonness of the idea in Bengaluru and Hyderabad locale. Along these lines, large amounts of usage of the idea 'Consistent Learning' are affirmed by the exploration.

\section{ASSESSMENT}

High positioning for a component, high positioning for three components and impartial positioning for three components preludes the scientist to prescribe the high centrality joined to the idea in Bengaluru and Hyderabad areas in the specimen IT associations.

Table. No 1.4

\begin{tabular}{|c|c|c|c|c|c|c|c|c|c|c|c|c|c|c|}
\hline \multicolumn{15}{|c|}{ Continuous Learning - Income wise } \\
\hline & \multicolumn{7}{|c|}{ Bengaluru } & \multicolumn{7}{|c|}{ Hyderabad } \\
\hline Element $\quad$ occupation & $\begin{array}{r}2 \mathrm{~L}- \\
3.5 \mathrm{~L}\end{array}$ & $\begin{array}{l}>3.5 \mathrm{~L}- \\
5 \mathrm{~L}\end{array}$ & $\begin{array}{l}>5 \mathrm{~L}- \\
6.5 \mathrm{~L}\end{array}$ & $\begin{array}{l}>6.5- \\
8 \mathrm{~L}\end{array}$ & $\begin{array}{l}>8 \mathrm{~L}- \\
9.5\end{array}$ & $>9.5$ & CWA & $\begin{array}{l}2 \mathrm{~L}- \\
3.5 \mathrm{~L}\end{array}$ & $\begin{array}{l}>3.5 \mathrm{~L}- \\
5 \mathrm{~L}\end{array}$ & $\begin{array}{l}>5 \mathrm{~L}- \\
6.5 \mathrm{~L}\end{array}$ & $\begin{array}{l}>6.5- \\
8 \mathrm{~L}\end{array}$ & $\begin{array}{l}>8 \mathrm{~L}- \\
9.5\end{array}$ & $>9.5$ & CWA \\
\hline $\begin{array}{l}\text { Employee identification of } \\
\text { skills for future task } \\
\text { accomplishment }\end{array}$ & 4.08 & 4.07 & 3.93 & 3.92 & 3.94 & 3.99 & 3.99 & 4.00 & 4.06 & 4.04 & 4.03 & 4.00 & 3.94 & 4.01 \\
\hline
\end{tabular}




\begin{tabular}{|c|c|c|c|c|c|c|c|c|c|c|c|c|c|c|}
\hline $\begin{array}{l}\text { Mutual Employee Efforts at } \\
\text { Learning }\end{array}$ & 3.00 & 2.97 & 3.02 & 3.05 & 2.98 & 2.96 & 3.00 & 3.00 & 3.00 & 3.00 & 3.03 & 3.00 & 2.93 & 2.99 \\
\hline $\begin{array}{l}\text { Availability of fund and } \\
\text { other resources for Employee } \\
\text { to support their learning }\end{array}$ & 2.83 & 2.93 & 3.00 & 3.03 & 2.99 & 2.90 & 2.92 & 3.08 & 3.11 & 3.04 & 3.00 & 3.04 & 2.96 & 3.04 \\
\hline $\begin{array}{l}\text { Availability of time to } \\
\text { support learning }\end{array}$ & 2.83 & 2.93 & 3.00 & 3.03 & 2.99 & 2.90 & 2.92 & 3.08 & 3.11 & 3.04 & 3.00 & 3.04 & 2.96 & 3.04 \\
\hline $\begin{array}{l}\text { Employee treating job } \\
\text { related problems as an } \\
\text { opportunity to learn }\end{array}$ & 3.17 & 3.03 & 3.04 & 3.07 & 2.97 & 2.92 & 2.95 & 3.00 & 3.00 & 3.08 & 3.03 & 3.06 & 2.97 & 3.02 \\
\hline $\begin{array}{l}\text { Reward to encourage } \\
\text { employee learning }\end{array}$ & 4.08 & 4.14 & 4.07 & 4.02 & 3.97 & 3.99 & 4.00 & 4.08 & 4.11 & 4.08 & 4.00 & 4.02 & 3.95 & 4.04 \\
\hline Average & 3.27 & 3.29 & 3.29 & 3.31 & 3.25 & 3.22 & 3.25 & 3.33 & 3.35 & 3.31 & 3.30 & 3.30 & 3.24 & 3.31 \\
\hline
\end{tabular}




\section{STATUS}

Table 1.4 shows 'High' positioning for 'Prize to empower representative adapting', "High" positioning for 'Worker recognizable proof of abilities for future undertaking achievement', and 'Common Employee Efforts at Learning' and "Impartial" positioning for 'Worker Learning Through Open Discussion on Mistakes', 'Accessibility of store and different assets for Employee to bolster their learning', 'Accessibility of time to bolster learning' and 'Worker regarding employment related issues as a chance to learn' as mark by the philosophy of the example respondents, this is existing among the distinctive occupations for the predominance of the idea in Bengaluru and Hyderabad locale. Along these lines, high, high and nonpartisan levels of usage of the idea 'Consistent Learning' are affirmed by the exploration.

\section{ASSESSMENT}

High positioning for a component, high positioning for two components and unbiased positioning for four components preludes the analyst to prescribe the high importance connected to the idea in Bengaluru and Hyderabad districts in the specimen IT associations.

\section{FINDINGS}

Constant Learning

Age

High positioning for two, Neutral for four and low for one component at Hyderabad.

High positioning for six and Neutral for one component at Bangalore.

\section{Sex}

High positioning for five and Neutral positioning for two components at Hyderabad.

High positioning for three and Neutral positioning for four components at Bangalore.

\section{Instruction}

High positioning for two and Neutral positioning for five components at Hyderabad.

High positioning for three and Neutral positioning for four components at Bangalore.

\section{Occupation}

High positioning for a component, high positioning for three and unbiased positioning for three components in Bangalore and Hyderabad.

\section{Salary}

High positioning for a component, high positioning for three and unbiased positioning for three components in Bangalore and Hyderabad.

\section{CONCLUSIONS}

Sustenance of backing for six and improvement of backing for solitary component 'Common Employee Efforts at Learning' at Bangalore; and food of backing for two 'Worker recognizable proof of aptitudes for future undertaking achievement, Reward to empower representative learning' and upgrade of backing for five components at Hyderabad. Promotion for three components 'Representative learning through Open Discussion on Mistakes, Employee distinguishing proof of abilities for future undertaking achievement, Reward to energize worker learning' 
and improvement of backing for four components in Bangalore area; sustenance for five components and enhancement of backing for two components 'Representative Learning Through Open Discussion on Mistakes Mutual Employee Efforts at Learning' in Hyderabad locale. The study finishes up upkeep for three components and change of backing for four components in Bangalore locale; support for two components and change of backing for five components in Hyderabad district. The study finishes up upkeep for four components and change of backing for three components in Bangalore and Hyderabad locales. The study finishes up upkeep for four components and change of backing for three components in Bangalore and Hyderabad locales.

\section{REFERENCES}

Argyris, C. (1991), “Teaching smart people how to learn”, Harvard Business Review, 70 (3):327-340.

Bao, M. X., \& Chao, B. (2015). Conclusions Of Learning And Conditioning Furthering Modern Day Efficient Organizational Behavior. Scholedge International Journal Of Management \& Development ISSN 2394-3378, 2(4), $1-6$.

Bozie, M. (2015). Impact Of Technology On Teaching Methods-A Forward Look. Scholedge International Journal Of Management \& Development ISSN 2394-3378, 1(1), 34-43.

Burgoyne, J., Pedler, M. and Boydell, T. (1994), Towards the Learning Company. McGraw-Hill, London.

Chan, C. (2003). "Examining the relationship between individual, team and organizational learning in an Australian hospital". Learning in Health and Social Care, 2(4), 223-235.

Cyril Kirwan, Making sense of organizational learning: putting theory into practice. http://www.gowerpublishing .com/isbn/9781409441816.

David A. Garvin, Amy C. Edmondson, and Francesca Gino, (2008), “Is Yours a Learning Organization?” Harvard Business Review, 86(3): 101.

Digenti, D. (1998). "Toward an Understanding of the Learning Community", Organizational Development Journal, 16(2): $91-96$.

Garvin D.A, (1993), “Building a learning organization”, Harvard Business Review, 71(4): 78-91

Kavita Singh, (2010), “An Analysis Of Relationship Between The Learning Organization And Organization Culture In Indian Business Organization”, Organizations And Markets In Emerging Economies, 1 (1).

Kontoghiorghes. C, Awbrey, S. \& Feurig. P. L. (2005). Examining the relationship between learning organization characteristics and change adaption, innovation and organizational performance, Human Resource Development Quarterly, 10(2), 185-211.

Lima, C. C. (2015). Role Perception In The Organizational Behavior For The Organizational Innovation Accord. Scholedge International Journal Of Management \& Development ISSN 2394-3378, 2(3), 14-18.

Mike Pedler, John Burgoyne \& Tom Boydell, 1997. The Learning Company: A Strategy for Sustainable Development $2^{\text {nd }}$ Ed. McGraw-Hill

Peter Senge, 1990. Fifth Discipline: the art and practice of the learning organization. Random House Audion. ISBN- 10: 0553456342, ISBN-13: 978-0553456349

Popper, M. \& Lipshitz, R. (2000). "Installing mechanisms and instilling values: The role of leadership in organizational learning”. The Learning Organization, 7(3), 135-144. 
Powell, B., \& Rose, M. (2015). The Critical Analysis Of The Theory Of Foundationalism As A Structure Of Education. Scholedge International Journal Of Multidisciplinary \& Allied Studies ISSN 2394-336X, 2(1), 5-8.

Ratner, S. (1997), "Emergine Issues in Learning Communities". St. Albans, Vermont, Yellow Wood Associates, Inc.: $1-34$.

Redding, J. (1997), "Hardwiring the Learning Organization", Training \& Development, 51(8), 61-67.

Richa Awasthy, Rajen K. Gupta, (2011) "Is learning orientation in manufacturing and service firms different in India?" Learning Organization, The, 18(5): 392 - 408.

Saha, B. (2015). Curators Plan To Business Ethical Dilemma-A Roadmap To Handle Ethical Behavior Of The Business Organizations. Scholedge International Journal Of Business Policy \& Governance ISSN 2394-3351, 2(6), $1-4$.

Sharma, R., \& Writer, M. S. (2015). Cognitive-Behavioural Approach In Mentoring College Students For Personal Effectiveness: An Empirical Study. Scholedge International Journal Of Multidisciplinary \& Allied Studies ISSN 2394-336X, 2(5), 36-42.

Watkins, K. E., \& Marsick, V.J. (1993). Sculpting the learning organization: Lessons in the art and science of systematic change. San Francisco: Jossey-Bass.

Watkins, K. E., \& Marsick, V.J. (1996). "In Action: Creating the learning organization”. Alexandria, VA: American Society for Training and Development.

Watkins, K. E., \& Marsick, V.J. (1996). Facilitating learning organizations: Making learning count. Aldershot, England: Gower.

Watkins, K. E., \& Marsick, V.J. (2003). "Demonstrating the value of an organization's learning culture: The Dimensions of Learning Organizations Questionnaire". Advances in Developing Human Resources, 5, 132-151. 